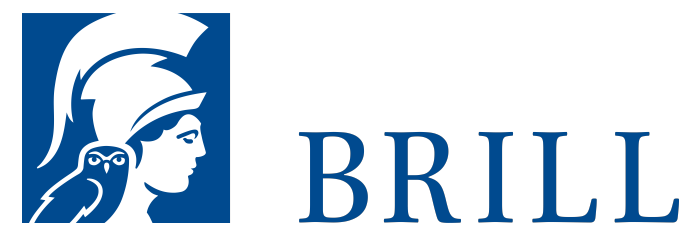

\title{
Judicial Practice
}

Institutions and Agents in the Islamic World

Author: Bogaç A. Ergene

This book brings together edited articles from the second and third editions of the Encyclopaedia of Islam that are relevant to Islamic judicial practice, institutions, and agents. The material presented in this compilation identifies and explains key concepts germane to the application of Islamic law. It demonstrates the wide spectrum of variations in the functions and operations of judicial actors and institutions in different Islamic contexts, and reveals the complicated relationship between legal doctrine and practice. As such, this book constitutes a much-needed introductory volume and a convenient starting-point for readers interested in Islamic judicial practice.

\section{Readership}

All those interested in Islamic law, Islamic judicial practice, and Islamic judicial institutions and actors. Also readers interested in comparative legal anthropology.



Language:

English

Subjects:

General, Middle

East and Islamic

Studies

Publisher: Brill

Series:

EI Reference

Guides, Volume:

2

E-Book (PDF)

Released online: 26 Oct 2009

ISBN: 978-90-

47-44169-4

Hardback

Publication date: 26 Oct 2009

ISBN: 978-90-

04-17934-9

List price

USD $\$ 268.00$ 
Bogac A. Ergene, Ph.D. (2001) in History, Ohio State University, is Associate Professor at the University of Vermont. He has published extensively on Ottoman legal history, including Local Court, Provincial Society and Justice in the Ottoman Empire (Brill, 2003).

For more information see brill.com

Order information: Order online at brill.com +44330 3330049 | customerservices@brill.com Submission information: brill.com/authors

Titles published by Brill | Fink, Brill | mentis or Brill | Schöningh: +49(o)71 5413279216 | brill@brocom.de 